\title{
ABNER KNEELAND: HIS RELATIONS TO EARLY IOWA HISTORY.
}

BY MARY R, WHITCOMB.

We have had revolutionary orators, reformers, martyrs; it was but a few years since Abner Kneeland had been sent to jail for expressing an opinion about the great First Cause.-OLIvER WeNDELL HoLmes.

Abner Kneeland, one of the scholars and thinkers of the day.-JUDGE GEORGE G. WRIGHT.

\section{CAREER BEFORE COMING TO IOWA.}

During the earlier part of the last century Abner Kneeland was a name well-known in all parts of New England. According to one's views the man who bore it was praised as standing for freedom of speech and liberty of conscience, or denounced as an "atheist" and "revolutionist" whose dangerous teachings would undermine the foundations of religion and society. He died in 1844 , nearly sixty years ago, and it may not be generally known that he spent the last tive years of his life in Iowa, and that his remains now lie buried in Iowa soil. Van Buren county claims many distinguished men among her citizens; with them must be numbered Abner Kneeland.

He was born in Gardner, Mass., April 7, 1774, on the eve of the revolutionary war, in which his father served; the fourth son of Timothy and Martha (Stone) Kneeland.* The Kneelands were originally a Scotch clan, their ancestry dating back to the days of Wallace and Bruce. Abner's early life was spent on a farm, and his educational advantages were limited to the common schools of Gardner and one term in the academy at Chesterfield, N. H. However he acquired much by his own efforts, a knowledge of the Hebrew, Greek and Latin languages, and became a noted preacher and writer.

*For facts in the hife of Kneeland, see "Seven Centuries in the Kneeland Family." (by a nephew, Stillman F. Kneeland, Judge Advocate General of the state of New York), New York, 1897; the writer has also made use of a journal kept by Abner Kneeland with occasional entries from 1812-1820. 

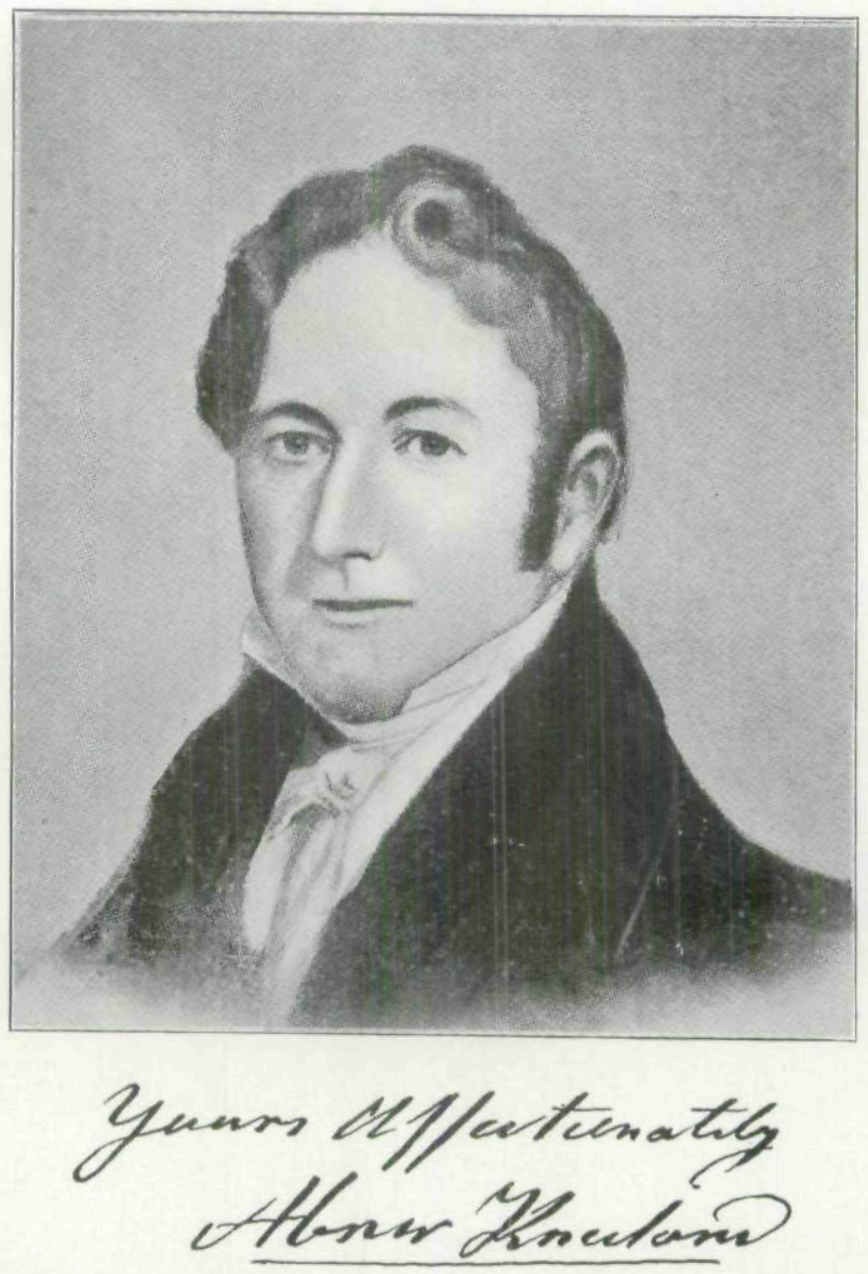

ABNER KNEELAND, 1774-1844; THE ORIGINAL OIL PORTRAIT IS OWNED BY BIS DAUGHTER, MRS. BOLER, OF FARMINGTON, IOWA. 
When about twenty-one years of age, he went to Dummerston, Vt., where he worked for a time at the carpenter's trade, and also taught school. While there he was "converted," immersed and joined the Baptist church. For a brief time he preached for the Baptist denomination, but he soon wavered in the faith, and there was talk of dealing with him for heresy. A few years later he declared himself a Universalist in belief and in $\mathbf{1 8 0 3}$ he was licensed as a Universalist preacher. He began work in Langdon, N. H. In that town, as was the wont of New England towns, money to sustain religious services was raised by public taxation, and it was there divided between the Congregationalists and Universalists. For a time he preached for both denominations, but on October 30, 1805, he was regularly ordained as pastor of the Universalist church. The Rev. Hosea Ballou, a man brought up in the Baptist faith, but who had become a well-known Universalist, preached the sermon and extended the "right hand of fellowship." Mr. Kneeland's pastorate at Langdon extended from 1805 to 1811 . During that period he was elected to the House of Representatives in the New Hampshire legislature, serving in 1810 and 1811. From 1812-14 he was pastor of a church in Charlestown, Mass. Religious doubt again assailed him and he engaged for a time in the merchandise business in Salem, Mass. At his solicitation a correspondence began with his friend the Rev. Hosea Ballou, on the authenticity of the scriptures.* Ten letters were written by each, when Mr. Kneeland acknowledged satisfaction, and expressed his release from doubt.

He resumed preaching and in 1817 held a short pastorate in Whitestown, N. Y. In 1818 he became pastor of the Lombard Street Universalist church in Philadelphia, where he remained seven years. While there he edited the Uni-

\footnotetext{
*Afterwards published, "Series of Letters in Defence of Divine Revelation; in Reply to the Rev. Abner Kneeland's Serious Inquiry into the Authenticity of the Same," by Hosea Ballou. Salem, Mass., 1816; 2d ed. Boston, 1820. (See, "Biography
of Rev. Hosea Ballou," Boston, 1853, p. 96).
} 
versalist Magazine and Christian Messenger, published a version of the New Testament translated from the Greek, held a debate with the Rev. W. L. McCalla, on the subject of universal salvation,* and lectured extensively. His discourse was almost entirely controversial, as was that of the Universalist ministry everywhere at the time.

$\mathrm{Mr}$. Kneeland was a pioneer in phonetic reform, making, about 1824, an attempt to rid our language of silent letters. He originated a new alphabet with a character for each vowel sound and claimed for his system that it abridged the language one sixth part; that children could learn it in one tenth the time ordinarily required, and that it would lessen the size and expense of books. In 1827 he published a "Key to the new System of Orthography," and advertised it extensively during the following year, giving many specimens to the public. $\dagger$ The system received recommendations from ministers, lawyers, doctors, teachers, principals of select seminaries for young ladies, etc. On the other hand it was characterized as visionary and impracticable, and such notices as the following must have been discouraging, "We would remind the ingenious inventor of these elegant hieroglyphics, that two things are wanting in order to secure the success of his plan; one is public opinion and the other any possible utility to be derived from its adoption." On leaving Philadelphia he took charge of the Prince Street Universalist church, New York city. In 1827, while pastor of that church, Mr. Kneeland's boldness in preaching caused uneasiness and finally led to a serious division among the members of the church and to his resignation. He at once became the leading editor of the Olive Branch, a Universalist weekly paper, published by the New York Universalist Book Society, of which he was then president. The title of the paper seems a misnomer, for although its pages were embellished by the cut of a dove bearing the emblem

*Afterwards published in book form.

$\dagger$ A specimen is given in the Olive Branch, May 19, 1827, p. 8. 
of peace, it was largely devoted to controversy. Kneeland's differences with the New York church, and later with the Hudson River Universalist Association, were given much space, and referred to again and again. He had, however, many sympathizers and in June, 1827, the Second Universalist Society of New York* was organized, and the Rev. Abner Kneeland established as pastor. Services were at first held in Tammany Hall, and later in the new Masonic Hall. About this time Mr. Kneeland became sole editor of the consolidated Olive Branch and Christian Inquirer, a weekly devoted to "free inquiry, pure morality and rational christianity." He grew more outspoken in his religious doubts, which finally obtained the mastery. The Universalists refused longer to recognize him as a preacher, and in May, 1829, after nearly twenty-five years of ministerial labor he suspended himself from the church, giving a clear and dignified statement of his position. The immediate influence at this crisis was the reading of the works of Joseph Priestley, the eminent physicist. He states that in reading the "Disquisition on Matter and Spirit," he became a materialist and "in spite of all his efforts to prevent it, the whole fabric of Christian evidence was completely demolished in his mind, without leaving even a wreck behind."

In April, 1831, Abner Kneeland founded a weekly paper in Boston, the Investigator, $\nmid$ an organ of free thought, and became the leader of the First Society of Free Enquirers in that city. The society was organized with officers, auditor, treasurer and trustees, and held meetings in Julien Hall. This movement is probably explained by the fact that about this time Mr. Kneeland was closely associated with the two reformers Robert Dale Owen and Frances Wright. $\$$ A full account of the ideas for which they stood

*The constitution of this society is published in the Otive Branch, June 30, 1827.

$\dagger$ The Investigator, "anti-religious," is still published weekly at Boston.

$¥$ Frances Wright (afterwards married to M. Darusmont), philanthropist and reformer, was born in Dundee. Scotland, Sept. 6, 1795. She early adopted the philosophy of the French materialists; was in the U. S. 1818-21; visited France at the invi- 
and of the experiments at New Harmony, Ind., and Nashoba, Tenn., is found in McMaster's history.* "Fanny Wright Societies' were formed in many towns and cities, the reforms she advocated were seriously undertaken, and New York city made the centre of the new movement. To it in 1829 the New Harmony Gazette was removed and issued as the Free Enquirer." $\dagger$ As early as 1827 Kneeland's "Owenism" was mentioned. While the Free Enquirer was being published in New York, he was editor of the Olive Branch in the same city. Frequent communications from him and frequent notices of his meetings appear in the former paper, and he often exchanged with Robert Dale Owen in addressing their respective congregations.

On the occasion of the celebration of Thomas Paine's birthday, Jan. 29, 1833, in New York city, "Abner Kneeland and his co-adjutors in Boston" $\ddagger$ were publicly toasted, as were Robert Dale Owen and Frances Wright Darusmont. In Providence, R. I. on the same occasion, this toast was proposed-"Frances Wright, Robert Dale Owen and Abner Kneeland, champions in the cause of buman emancipation. May they never lack for support." || In Philadelphia also, toasts were proposed to "Abner Kneeland-the greatest obstacle in the way of the New England clergy" and to "Ballou, Palmer, Godwin, Taylor and Kneeland-seceders from the ranks of Priesthood."§

In March, 1837, Abner Kneeland and Frances Wright Darusmont were associated as editors of the Investigator; the latter retired in 1838 leaving Kneeland sole editor, who contin-

tation of Lafayette; returned in 1825 and purchased 2400 acres of land in Tenn., where she made her experiment for the betterment of the colored race. Later she was associated with Robert Dale Owen in the New Harmony, Ind,, communistic enterprise. She lectured on religious, political and social questions. Her freedom of speech caused great opposition from church and press. She died in Cincinnati, Ohio, Dec. 14, 1852.

*Vol. 5, chap. 43.

$\dagger$ "History of the People of the U. S.," vol. 5, p. 99.

$\ddagger$ Free Enquiver, N. Y., vol. 5, p. 124.

\|Free Enquirer, N. X., vol. 5, p. 135.

\$Free Enquirer, N. Y., vol. 5, p. 160. 
ued as such until December 25, 1839, when he was succeeded by Horace Seaver. The heading of the paper in 1837 included these words: "issued every Friday under the superintendence of a society of gentlemen," "deroted to the protection and development of American principles" (later "liberal" was substituted for "American," and in May, 1842, "infidel" for "liberal"); "truth, perseverence, union, justicethe means; happiness - the end. Hear all sides - then decide." The paper took advertisements more cheaply from those who supported it than from others, and at one time the price of subscription was announced as varying from $\$ 2$ to $\$ 5$ per annum according to the means of the subscriber. There was always a large amount of contributed matter, and the vogue of the paper seems to have been largely among the common people. In one article he calls the farmers and mechanics the "bone and muscle of the community," and he evidently thought of his paper as a democratic one. It reached the west quite extensively. He made frequent complaints that subscribers were in arrears, and after retiring from the editorship he writes that he is afraid the paper must stop. Meetings of friends were called several times to see whether the paper could still continue. The prospectus of February 22,1839, however, states there were at that time over 2,000 subscribers and that the paper began with only 250. From the first the paper attracted attention and met with pronounced opposition.

Those were stirring times in the intellectual and religious life of New England, with Harvard as a center. A group of brilliant men were speaking and writing in the interests of new and broader movements of thought. Among these were William Lloyd Garrison, Theodore Parker, O. A. Brownson, George Ripley, Alcott, Channing and Emerson. The ideas of the French revolutionary period were prevalent, and Adam Smith, Rousseau and Paine were much read. Among the signs of the "general ferment" of the times was 
Abner Kneeland's Investigator, "its temper that of Thomas Paine, but more negative in theology."

Kneeland was finally arrested on the charge of blasphemy. The article objected to was written by himself and published in the Investigator, December 20, 1833. It read as follows:

1. Universalists believe in a God which I do not; but believe that their God, with all his moral attributes (aside from nature itself) is nothing more than a chimera of their own imagination.

2. Universalists believe in Christ, which I do not; but believe that the whole story concerning him is as much a fable and fiction as that of the god Prometheus, the tragedy of whose death is said to have been acted on the stage in the theater in Athens five hundred years before the Christian era.

3. Universalists believe in miracles, which I do not; but believe that every pretension to them can be accounted for on natural principles, or else is to be attributed to mere trick and imposture.

4. Universalists believe in the resurreetion of the dead, in immortality and eternal life, which I do not; but believe that all life is mortal, that death is an extinetion of life to the individual who possesses it, and that no individual life is, ever was, or ever will be eternal.

He was tried before the municipal court of Boston, in January 1834 , convicted and sentenced to three months' imprisonment in the common jail. He appealed to the supreme court of Massachusetts, and in May, 1834, was tried before Judge Samuel Putnam; the jury disagreeing, the case was again tried, before Judge Samuel Wilde, Nov., 1835; a new trial was moved, the case was continued, and finally in 1838, Kneeland was sentenced to sixty days' imprisonment. The Attorney General of the state of Massachusetts, who argued the case at the final trial, was James T. Austin, who "won imperishable renown" by prosecuting Abner Kneeland and defending the murder of Lovejoy. The defendant claimed that the act against blasphemy on which the indictment was founded, was contrary to the constitution of Massachusetts, and also in conflict with and contrary to the laws on naturalization made by Congress. He also denied that the objectional words, if construed as he meant them were blasphemy. "I had no occasion to deny that there was a God; I believe that 
the whole universe is nature, and that God and nature are synonymous terms. I believe in a God that embraces all power, wisdom, justice and goodness. Everything is God. I am not an atheist but a pantheist."

A full report of this trial, "the inquisition of Boston," is found in Pickering's Mass. Reports, vol. 20, pp. 206-46; Mr. Andrew Dunlap's speech for the defence (begun at 12 o'clock Tuesday and concluded at 4 p. m. Friday) was printed and widely circulated. "It advanced a manly exposition of the rights of conscience." Mr. Kneeland's speech in his own defence was printed (J. Q. Adams, Boston, 1836); the arguments of S. D. Parker, Attorney for the Commonwealth were also published (Beals, Homer \& Co., Boston, 1834). $†$

The conviction and imprisonment of Kneeland raised a storm of protest. A petition signed by 168 persons, William Ellery Channing's name heading the list, was presented to the Governor of Massachusetts. It asked for unconditional pardon. It was in turn bitterly attacked, a remonstrance was circulated and it was rejected by the Governor and council. "Nevertheless, it exerted a wide and permanent influence. It was an assertion by Christians of the equal rights of atheists to freedom of thought and speech. It did a good work in educating the public mind. And there will never, in all probability, be another prosecution for atheism in Massachusetts." It is interesting to note some of the comments made at the time. An editorial in the Windsor, Vt., Statesman, declared that if Kneeland could not speak his mind the very cause for which the Pilgrims came was overthrown; "With Mr. Kneeland's principles we have nothing to do. We believe them wrong; but the Constitution throws its broad shield

*Pickering's Mass. Reports, vol. 20, p. 209.

†See also "Appeal to Common Sense and the Constitution, Occasioned by the Trial of Kneeland for Blasphemy." Anon., Boston, 1834. "Introduction to the Defence of Abner Kneeland, charged with Blasphemy." Boston, 1854. Speech in his own defence Nov,, 1834. "Review of the Prosecution against Kneeland." D. Henshaw. Boston, 1835.

¥"Life of William Ellery Channing," Boston, American Unitarian Asso., 1899, p. 506. 
over and around him as well as his persecutors. He has his constitutional rights and these have been trampled upon." Garrison denounced the trial as "a disgrace to the Commonwealth of Massachusetts, and a proof of the corruption of modern Christianity." Mr. Garrison had reason to feel kindly toward Kneeland, for it was at Julien Hall, at the latter's invitation, that his first anti-slavery lecture in Boston was delivered, October 15, 1830. For two weeks Garrison had tried to secure a place in which to lecture, and he finally placed an advertisement in the Courier. "This appeal was quickly answered, but not by any of the Christian ministers or churches of Boston. It was left for a society of avowed 'infidels' to save the city from the shame of sealing all its doors against the slave's advocate." $\dagger$ About this time Theodore Parker, writing to a classmate, says, "I detest this bolt-andshackle business as applied to thought. Pray let men think as they please, without fearing the stocks, if they do not think just as their fathers did a thousand years ago."

In July, 1838, Emerson delivered his famous address before the graduating class of the Divinity School of Harvard. It was considered rank heresy. Theodore Parker again writing of "our old friend Kneeland" says: "Abner was jugged for sixty days; but he will come out as beer from a bottle, all foaming, and will make others foam-the charm of all is that Abner got Emerson's address to the students, and read it to his followers, as better infidelity than he could write himself." $\$$ The International Cyclopedia speaking of this trial says: "There has been no prosecution under the statute since that day, though hundreds of men have avowed their disbelief in God in terms far more offensive than those used by Mr. Kneeland. Public opinion upon the freedom of the press has greatly changed."

A curious commentary on those times is found by read-

*Boston Liberator, vol. 8, p. 107.

†"William Lloyd Garrison," N. Y., The Century Co., 1885, vol, 1, p. 212.

ఫ"Memoir of Bronson Alcott," Boston, 1893, vol. 1, p. 281. 
ing the address of the Attorney of the Commonwealth, made at the trial. It is full of extravagant denunciation of the "pernicious doctrines" of Robert Dale Owen and "Fanny" Wright, and of Kneeland as their "Lieutenant General." The jury is urged to let nothing prevent their "seeing and abhoring Abner Kneeland and his detestable dissemination of obscenity, and impiety and blasphemy-this defendant who may be considered from his acts and doctrines to be the common enemy of the human race."* To most readers at this day the extreme bitterness seems ludicrous as well as unpardonable. One thinks of the tribute paid Frances Wright in the Dictionary of National Biography (London), "It is to Frances Wright's lasting honor that she was almost the first to discern the importance of the slavery question, and to endeavor to settle it on a basis of amity and good feeling, to the mutual advantage of all concerned," and of Mrs. Trollope's description of her "tall and majestic figure, the deep and almost solemn expression of her eyes, her finely formed head." As to the private character and morals of Abner Kneeland, they were above reproach. The thoughtful person can imagine his bitterness of soul at the injustice and humiliation heaped upon him, and wonders how he could ever recover from it. It is probable he never did. His influence waned. Although the best men of the day were champions of his right to freedom of speech, and denounced the injustice of his trial and imprisonment, there is a notable lack of expressions of personal friendship. Furthermore, his frequent changes of belief doubtless alienated those blessed with more stability.

CAREER IN SALUBRIA, IOWA.

In 1839, Abner Kneeland came to the new, far-a-way Territory of Iowa. The east had persecuted and imprisoned him. He turned to the west for freedom and understanding; where, alas, he found much of the same intolerant spirit.

\footnotetext{
*"Report of the Arguments of the Attorney of the Commonwealth at the Trial of Abner Kneeland." Beals, Homer \& Co., Boston, 1834, p. 35.
} 
In 1837 or 1838, it appears that the First Society of Free Enquirers of Boston, of which he was leader, formed a plan to found a colony in the west, and selected as the site, a place two miles south of Farmington, Van Buren county, calling it Salubria. The members interested evidently drew lots for land already accessible, expected to send out Kneeland and other commissioners and to get more land through them. A local history of Van Buren county states that an assessment of ten dollars was levied on each member to further the scheme.* Many questions arise as to the nature of the society (probably one of the "Fanny Wright" societies) and of its western project. Accurate information is hard to obtain, but the plan for a colony in the sense of an organized association, for some reason never materialized. The settlement at Salubria was largely Kneeland's personal enterprise. The statement that "Abner Kneeland of Boston planned a socialistic commonwealth in the Des Moines Valley," $\dagger$ is, however, erroneous. There was nothing either socialistic or communistic about Salubria. It seems probable that Kneeland published a prospectus of Salubria in some of the papers in which he was interested, between the years 1837 and 1839 , but only the following notice has been found. It appeared in the Investigator May 11, 1838. Tyler Parsons was doubtless one of Kneeland's business agents.

\section{NOTICE TO EMIGRANTS.}

The subscriber having recently arrived in Boston from the Far West, viz., Salubria Village, on the Des Moines river, south part of the Wisconsin Territory; and having purchased claims on lands for himself and others, the plan of the village will be executed immediately. A few of the village lots will be for sale. Actual settlers will be preferred. The lands in that region will be in the market soon. Any person wishing to be located in that healthy country may have an opportunity of purchasing a lot to locate their families in the village, until the lands shall be in market, as no person can well locate themselves in the purchase of a farm without taking time to ascertain all the circumstances relating thereunto.

*"History of Van Buren County," Chicago, 1878, p. 464.

†ANnals of Iowa, 3d ser., vol. 1, pp. 348-9. 
Any information relating to the subject of emigration to Salubria or any other place in the west, in possession of the subseriber, will be given with pieasure. Place of residence-dwelling home at the corner of Scott's Court, leading out of Union street, Boston.

April 23, 1838.

Tyler Pargons.

Nothing thus far found in the Van Buren county records, in the acts of the Iowa Territorial Legislature, or in the acts of Massachusetts (where the plan for the colony was made), leads to the conclusion that there was any corporation, municipal or private, which might have held title to any town site. Salubria was in its best days only a cluster of farm houses; it never developed into a town or trading point. Mail was sent to Farmington.

It is probable that the plan for a colony at Salubria was the first plan ever made for colonization in what is now the State of Iowa. At that time it was customary for towns to appear on paper before a house had been erected on their sites. These imaginary places were at a later time derisively called "stake towns." The plat of Salubria was lithographed on paper in Boston, but the writer has failed in the effort to secure a copy. Mr. E. R. Harlan, of the Keosauqua bar, a close student of the history of his county, has with great care searched for and copied the transfers of land owned by Kneeland, on file in the Recorder's office in Van Buren county.* These form the data from which he hopes to be able to reconstruct the original plat of

* Abner Kneeland to

Bill of Sale

Sept. 28, 1840 Silas Smith.

filed Sept. 29,1840

Salubria, September 28, 1840. Mr. Silas Smith bought of Abner Kneeland all the personal property now in the possession of Abner Kneeland and Dolly L. Kneeland, viz: 1 horse valued at 50-4 cows at 25 each $100-4$ yearlings valued at $8-32-4$ calves valued at 3 each 12-1 waggon, harness and saddle 30 . 20 hogs and 20 pigs $280-1$ secretary and book case $30-\mathrm{a}$ private library consisting of upwards of 200 volumes $100-434$.

Received payment,

Abner Kneeland \& wife

Elisha Cutler, Jr.

ABNer KNEel and.

Warranty Dead July 25, 1840

Filed Jan. 5, 1841

Certain lands in Lee county and "The north half of lot 8, and lots 13 and 14 of the front lots in Salubria, according to the first drawing, etc., as shown by a plan in the hands of Abner Kneeland and B. F. Tower." 
Salubria. This plat has been seen in Van Buren county, within a comparativèly short time. It was known to exist in 1886. Mr. Harlan has come within "exasperating distance" of it several times, but like the will-o'-the-wisp it evades the grasp just as one feels sure of securing it. It has probably been lost or destroyed.

A reference to the project of Salubria appears in the Investigator February 22, 1839, Kneeland then says, "The editor is about taking a tour to the Far West, on business of importance to himself, and to the cause of Free Enquiry, and will start early in the Spring." On leaving Boston he wrote a "Valedictory Address" * which appeared in the Investigator April 3, 1839. Among other things he says: "Whether I have anything or not worth seeking for in the Far West, depends on circumstances yet to transpire, and exertions yet to be made." This seems to indicate indefinite plans. On coming west Mr. Kneeland traveled by way of the Ohio and Mississippi rivers, stopping to deliver some addresses in the larger cities. His first landing in Iowa was at Fort Madison. His family followed, arriving at Salubria July 22,1839 , after 21 days enroute. His letters began to appear in the Investigator, March 27, 1839, and continued at intervals until January, 1840. The first was from Providence, R. I.; later ones were from New York, Philadelphia, Pittsburg, Cincinnati, and on board the Mississippi river boat "Knickerbocker." There are about 18 letters written from Salubria, the first one being dated May 19, 1839. They are all extremely interesting; they discuss the Territory of Iowa in general, the agricultural and commercial future of Salubria, the border troubles .with Missouri, the moral state of the community, the purchase of lands for friends in Boston, his own farming, etc. Some are devoted to special discussion with his old friend the Rev. Hosea Ballou, and there are many expressions of interest in the prosperity of the paper and the "Cause." After first com-

"Afterwards published ss a pamphlet and quite widely used. 


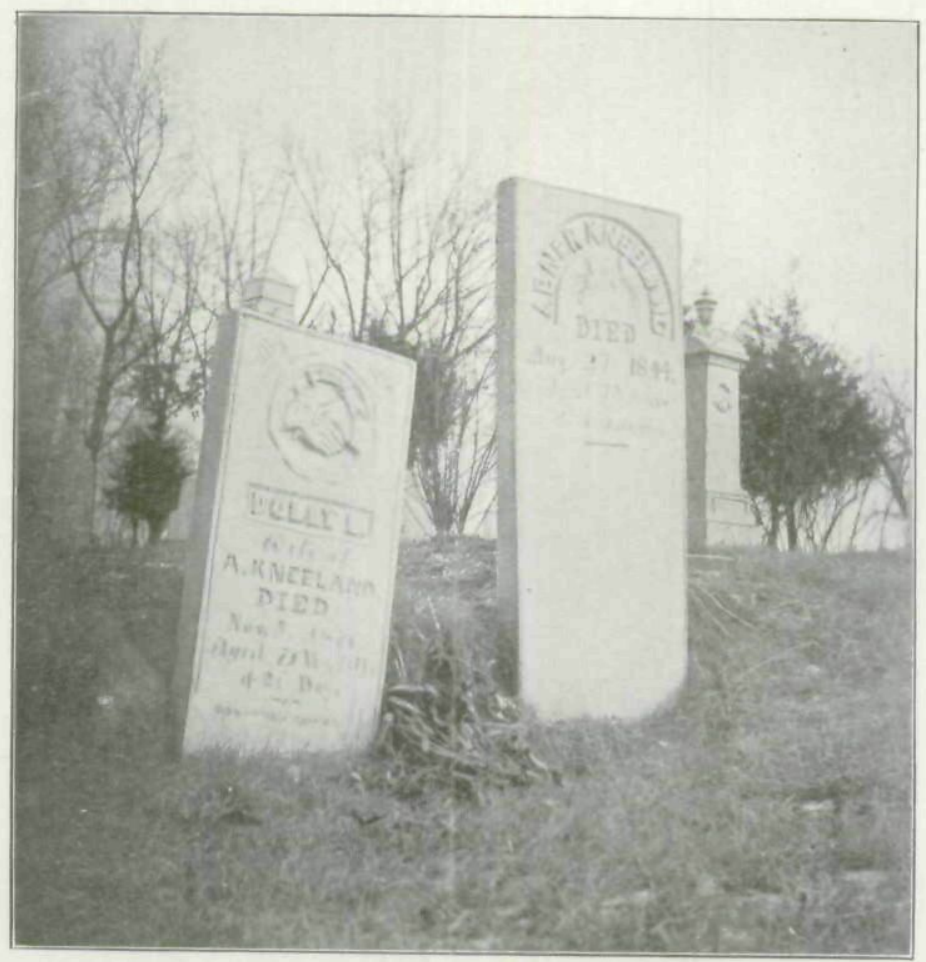

ABNER KNEELAND'S GRAVE IN FARMINGTON, TOWA, TO WHUCH HIS REMAINS WERE REMOVED FROM SALUBRIA IN 1881. 
ing to Iowa he makes many complaints that he is not receiving the paper and he seems to have taken always a paternal interest in it. A few passages or topics from his letters are quoted. The date of writing is given; they were generally printed a few weeks after, mails being slow and not very reliable.

May 19, 1839, (first from Salubria). "We struck bottom on the Des Moines river more than 100 times. Altogether the country is the best, and most beautiful I ever saw. We walked over our premises to-day, in company with the original proprietor. There is no part but what exceeds my expectation; and if there be any preference, those lots which were drawn to me and Mr. Rice are rather superior to the rest. The community needs a saw mill, grist mill, tan yard, ferry, public house of entertainment, etc." Rivalry with Farmington is recognized and discussed in fair spirit. "If I remain here, which I am now determined to do, unless sickness or death shall prevent, I hope and expect to see very great and rapid improvement going on in a short time."

May 23. "My thoughts are wholly taken up with this wonderful and beautiful country and making provision for my family when they shall arrive."

June 7. "Even aside from the persecution $I$ have endured in my native state, I know of no place in Boston that could afford me half the pleasure, as to the beanty and grandeur of the scenery, as it does to sit in my front door here and look across the Des Moines River; to see the large branching trees on the nearest bank and the beautiful green forest on the opposite side-this wonderful country which is destined to outvie everything which ean be even imagined in the East." (Refers to the Mormons.)

June 29. "I have had but very few opportunities as yet, to disseminate any of my views in relation to theology, as I advance them very cautiously: but whenever there is a chance without appearing intrusive I do not shrink from what appears to be a duty-a duty I owe to my fellow beings."

July 21. "I was making hay all last week, and therefore did not write."

A ugust 4. Announces that there is to be a sale of land in October, and gives notice to friends in Boston that they must send him their money if they wish to get it, as everybody on the spot is prepared. (The land sale by the United States Government referred to was postponed to March, 1840 , and there is no communication from Kneeland about it.)

August 18. "I had occasion to go to Farmington yesterday (Sunday); there seems to be some little movement there among religionists, such as prayer meetings, Sunday schools, etc., but I think they will not amount to much."

November 25. Reports death of Capt. John Kendall*-buried at his

*Father of Mrs. Elisha Cutler.

Vot. VI-23. 
own request on his own land. Kneeland officiated at the funeral and spoke, apparently "with great satisfaction."

January 29, 1840. On the occasion of Thomas Paine's birthday; on continuing the Investigator; on the Missouri boundary.

About this time Mr. Kneeland became active in Iowa territorial politics, which may account in part for the discontinuance of the letters. It is also probable that friends in Boston lost interest in the distant settlement. Mr. Kneeland was a democrat and in 1840 became a candidate for member of the upper house of the Iowa territorial legislature, then known as the Council. A democratic meeting was held at Salubria, April 7, 1840, with Zina Round, Jr., as chairman, Elisha Cutler, secretary. Among twelve resolutions adopted by the conventicn, numbers 5 and 11 read as follows:

5. Resolved, That in addition to the general invitation as above, Messrs. A. Kneeland, Z. Round, Jr., S. Smith, B. F. Tower and B. Wise, be and hereby are appointed to attend and represent this meeting at the said County Convention, who, we trust, will consider it their special duty to attend.

11. Resolved, That Messrs. A. Kneeland, S. Smith, and B. F. Tower, be a standing committee for one year to call future meetings whenever it shall be thought expedient.*

The democratic ticket nominated at this time, in Van Buren county, for the $3 \mathrm{~d}$ legislative assembly, was: Council, Gideon S. Bailey, Abner Kneeland; House, Zina Round, Jr., John M. Whitaker, William Steele. The ticket as elected was slightly changed: Council, Gideon S. Bailey, James Hall; House, Isaac N. Lewis, John M. Whitaker, William Steele. $\neq$ The Burlington Havk-eye and Iowa Patriot of October 15, 1840, contains this item, "Our old friend, Capt. Hall, beat the notorious Abner Kneeland for the Council in Van Buren county, by a handsome majority." In 1842 the "notorious" Kneeland was again active. $\mathrm{He}$ was elected chairman of the Van Buren county demo-

*Iowa Territorial Gazette and Burlington Advertiser, April 18, 1840.

†Iowa Territorial Gazette and Burlington Advertiser, Sept. 12, 1840.

$\ddagger$ Hawk-eye and Iowa Patriot (Burlington), Oct. 15, 1840. 
cratic convention, and a ticket was nominated supposed to be in sympathy with his views. Great alarm was felt. Party lines were ignored and many "church democrats" united with the whigs in supporting a union ticket to overthrow the "infidel party." After a bitter campaign the "Kneeland ticket," Council, Gideon S. Bailey, John Whitaker; Hoúse, Joseph Wright, Samuel Parker, William Hardy, ${ }^{*}$ was defeated and the following one elected for the 5th legislative assembly: Council, John D. Elbert, James H. Jenkins; House, Isaac N. Lewis, R. D. Barton, Samuel Swearingen. $\dagger$

What part of the opposition was due to the fact that the "Kneeland ticket" was democratic and what part due to the religious views it was supposed to represent it is hard to determine. One editor regretted that a "mongrel ticket" had been nominated in opposition to these gentlemen, and learned with surprise that the ticket was to be buoyed up by religious excitement; he says, "We hope sincerely that the good people of Van Buren county are not so far gone in bigotry as to attempt a conjunction of church and state-religion and politics." +

Dr. Gideon S. Bailey, the last surviving member of the democratic convention of 1842, died in November, 1903. Capt. Frederick Hancock, who died in October, 1903, was also a member of the convention and speaks thus of Kneeland: "He was a man of unimpeachable integrity and pure morals in social life, but saw in every effort made by those who differed with him a determination to bind his conscience." Of the convention Capt. Hancock says: "I was a member of that body and Mr. Kneeland, a fine looking, venerable, white-headed man, was quietly sitting by the table when the meeting began. Some one proposed him for chairman and it carried unanimously."

*Lee County Democrat, (Ft. Madison), July 9, 1842.

$\dagger$ Lee County Democrat, August 6, 1842.

$\ddagger$ Lee County Democrat, July 9, 1842. 
After coming to Iowa, Mr. Kneeland taught school for a short time in Helena, Arkansas. Judge James M. Hanks of that city, writes as follows:

Mr. Abner Kneeland taught school here for several months and I was one of his pupils. It must have been in 1841, '42 or ' 44 . He taught a common school, none of his pupils being over 10 or 12 years of age, and not well advanced for their years. He was I think competent and faithful, but very kind-hearted and indulgent. This may have been because of his advanced age. After he had been here some time, he spoke of his religious convictions but he was not offensive to his patrons in the declaration. He was above medium height, broad-shouldered, with florid complexion and very white hair. His pupils liked him very much because of his gentleness and kindness and their parents were satisfied with his work. He taught his school in the Methodist chureh, large, commodious, new, which in the absence of any other suitable or available building had been secured by the parents for his use. It was blown down, and totally destroyed in a storm and as no other suitable building could be secured Mr. Kneeland left.

In 1843, the "Iowa Band," a group of young Andover men, arrived on Iowa soil to preach the gospel. A few paragraphs from their writings will show how they regarded Kneeland and his followers. The Rev. Reuben Gaylord has this to say of Farmington and vicinity:

This place was situated in a delightful section of the country, on the Des Moines river, and in a few years was surrounded by a dense population. To the east bank of this beautiful stream came Abner Kneeland with a company of his followers, bringing with them the rankest atheism and infidelity, with Paine's Age of Reason and an atheistical catechism for their Bible, and pamphlets and newspapers of a similar character. They settled down about one mile from Farmington, and named the place Salubria. Kneeland boldly declared that there should be no Sabbath law in Iowa, and he and his followers determined to have nothing of a christian character about them so far as they could prevent it. In November, 1843, Rev. Harvey Adams, one of the Andover Band, took up his residence in Farmington. A better man could scarcely have been found. Many believed and his efforts were blessed to the conversion of not a few of Kneeland's deluded followers.*

New as Iowa was, there were ten places of ingress; a hundred families a day were pouring in. Four weeks planted ten thousand souls on the New Purchase. In 1841 the vigilant picket guard at Denmark had seen the westernmost gospel outpost established at Brighton, and his eye

*"Life and Labors of Rev. Reuben Gaylord," by his wife, Omaha, 1889, pp. 105-106. 
thenceforth was on the rich valley of the Des Moines. Kneelandism was popular but new settlements made liberal offers out of their poverty for the preaching of God's word. Atheism and Mormonism were then striving to get possession of our fair territory. One boasted that Tom Paine's Age of Reason would soon take the place of the Bible in all families of Iowa. Another that Mormonism would soon rise to the sovereignty in church and State. But twenty-one years have scarcely left a vestige of either.*

About this time Mormonism was sanguine. Its apostles were everywhere traversing the new settlements with a zeal and success at once astonishing and alarming. Infidelity too was presenting a bold front under the leadership of Abner Kneeland. He had settled with a band of his followers, male and female, upon the banks of the Des Moines, to mould if possible the faith of the new settlers by "substituting," as one has said, "Paine's Age of Reason, for the family Bible, the dance for the prayermeeting, and the holiday for the Sabbath."

The Rev. Daniel Lane, who went to Keosauqua in 1843 says:

At this early period, Van Buren county was considered one of the most important counties in the Territory, made so by both the number of its inhabitants and by the fact that it was the home of Abner Kneeland, and his infidel colony. Mr. Kneeland often lectured in Farmington, Bonaparte, Bentonsport and Keosauqua in the interest of his peculiar views and, of course, in opposition to Christianity. In entering upon my ministerial work in Keosauqua, however, I very soon made up my mind that the fundamental truths of the Gospel, and their practical bearing and influence in society, were what the people needed more than any discussion upon infidelity. This decision I saw no reason for reversing during my ten years of ministerial labor in the town. $\neq$

The Rev. Harvey Adams was the member of the band located at Farmington, and consequently the one most closely associated with Salubria. It is an interesting fact that when Mr. Adams was a boy, his father carried on the farm belonging to Mr. Kneeland's father-in-law, in Alstead, N. H., and the two families lived in the same house. Their mother having died, Mr. Kneeland's three children lived with their grandparents, and were often visited by their father. Years afterwards the two men met in Iowa,

*"Asa Turner and his Times," by Geo. F. Magoun, Boston, 1889, pp. 220-21.

†"The Iowa Band," by Ephraim Adams, rev. ed., Boston, p. 55.

¥"History of Van Buren County," Chicago, 1878, p. 475. 
under very different circumstances. Mr. Adams' daughter, Mrs. E. A. Babeock of New Hampton, Iowa, writes thus of their relations. "In an early day he (Mr. Kneeland) was a dangerous enemy to my father, but became a kind friend later. $\mathrm{He}$ and my father had many arguments on the subject of religion. He was a man of strong personality and very bright."

Abner Kneeland died suddenly at Salubria, August 27, 1844 , at the age of seventy. The first notice of his death in the Investigator appears September 25, 1844, the issue of that date being in part heavily ruled in black. An editorial praises him as an exemplary moral man, a good husband, father and citizen. It states his theology as follows: "He rejected theory after theory until he finally rested on the faith of a universal God-a one God-all things God-if a God there were, but of this being we could know nothing, and from him we had nothing, independent of this economy of things, to hope or fear."

Kneeland's death was the final blow to the Salubria settlement and it is now a waste place. He was four times married, and was the father of twelve children. His last marriage occurred in 1834 to Mrs. Dolly L. Rice, who with their oldest daughter, and her four children, James W., Dorcas, Dolly and Hannah Rice, followed him to Iowa. Two children were born in Salubria. A daughter, Mrs. Susan Rice Boler, resides in Farmington, and several grandchildren live in the State. Nearly all are members and workers in Christian churches. A chapel stands on ground once belonging to the "infidel settlement," in which a Sabbath school is held, presided over by a granddaughter of Abner Kneeland. The influence, however, that emanated from Salubria is undoubtedly felt in Van Buren county even at the present day, but in no aggressive form.

Among those associated with Mr. Kneeland were Silas Smith, B. F. and O. Tower, Capt. John Kendall, Samuel T. Twombly, Mrs. Pratt (afterwards Mrs. J. J. Kinersly of 
Keosauqua) and Elisha Cutler. Others sharing his views gathered about him and established homes in Van Buren county. They came west "in order to live and act as they wished with no one to molest."

For information regarding Abner Kneeland's life in Iowa, the writer is indebted to Mr. Voltaire Paine Twombly* of Des Moines, Captain of the Second Iowa Infantry, and for six years, 1885-91, State treasurer of Iowa, whose parents and uncle (Silas Smith), were prominent members of the settlement at Salubria, and whose cousin married James W. Rice, Kneeland's step-son. His father Samuel T. Twombly was at one time a Methodist minister, but adopted atheistical views. In 1838 he taught school in New Harmony, Ind., doubtless attracted hither by the Robert Dale Owen community; his school was held in the apartment used by the Working Men's Institute. In 1839 he went to Salubria and became a devoted admirer of Kneeland. A poem on Intolerance written by him closes with these lines:

\footnotetext{
Kneeland !-Freedom's best and noblest guide, Oh why do railing bigots him distress Who cries, "hear all sides-then decide," Bold and mighty champion of the press !
}

Mr. Twombly died at his home, "Ferney," near Salubria, in 1842 , at the age of 25 . Mr. Kneeland wrote an extended notice of his death for the Investigator, and requested all liberal papers to copy. In it he speaks of Mr. Twombly's devotion to the "cause of infidelity" and says, "to show his strong attachment to those sentiments, he named his son Voltaire Paine and the place of his birth Ferney, that being the name of the residence of the great philosopher Voltaire."

Elisha Cutler, served as clerk of the district court in Van Buren county, and in 1846 was elected the first Secretary of State of Iowa. James W. Rice was at one time mayor of Farmington, and for years Justice of the Peace.

\footnotetext{
*Capt. Twombly on August 19, 1903, delivered an address on Abner Kneeland before the Van Buren county Old Settlers' Association. It was published in the Keosauqua State Line Democrat, August 27, 1903.
} 
The families in Salubria were large, with many young people and children, and the social element was made much of. All in the settlement were great readers; books and papers were abundant, a condition not always found in pioneer homes. On first arriving Mr. Kneeland lived in a log cabin, as did the other settlers, but with his step-son he soon built the home which still stands. Mr. Harlan gives the following description made from personal observation:

I find the old house in a good state of preservation. It is very necessary to set out some of the environments in order to convey the correct impression of the house itself.

It will be remembered that Kneeland secured his patent from the government in December, 1841. That the Des Moines River country was a most enticing one, and proximity to the Mississippi a most advantageous thing. That the Missouri line, projected eastward to the Mississippi, marked the northern boundary of what was known as the "Half Breed Tract," wherein at that time and for years thereafter title to land was very uncertain. Hence, the first considerable improvement in the valley was adjoining and above this traet. Van Buren county held the first 30 or 35 miles of that valley, and Abner Kneeland secured the very first claim. That is, where the Missouri line intersected the north (or east) bank of the Des Moines River, it (the line) formed the south line of his claim.

The fact that Farmington and Keosauqua had been laid out and somewhat settled, needs only to be suggested to convey the full import of the inferior location of Salubria, else its site had been selected in 1837 by the early pioneers. The inferiority, however, of the Salubria site was one, most likely, of heavier growth of native trees, absence of a good landing on the river, and the unsettled location of the Missouri line. Therefore when Salubria was started it was done in the heart of a forest, on a level belt of bottom land bounded on one side by the river, on the opposite side and half a mile away by the hills, and on the other sides by deep ravines leading from the hills into the river about half a mile apart. A very sugar camp with its sheets of snow and ice in spring, its pond in summer, its tangled growth to be burnt off in autumn, and its solitary bleakness in winter time. Where this plain comes to the river, it breaks down some twenty feet into another belt about a hundred feet wide, which in turn breaks down thirty feet into the channel proper. Therefore the edge of Salubria rested about 50 feet from a level with the water, and a hundred back from its edge. An old trail followed the edge of this higher part, and this was appropriated for a boundary street of Salubria. Then on its north and east sides were laid out the lots, so far as oceupied, and back of them the streets and blocks of the town. There were then no openings in the woods. So when the colonists came, their allotments were made with relation to the Half Breed line, measured off, their build- 


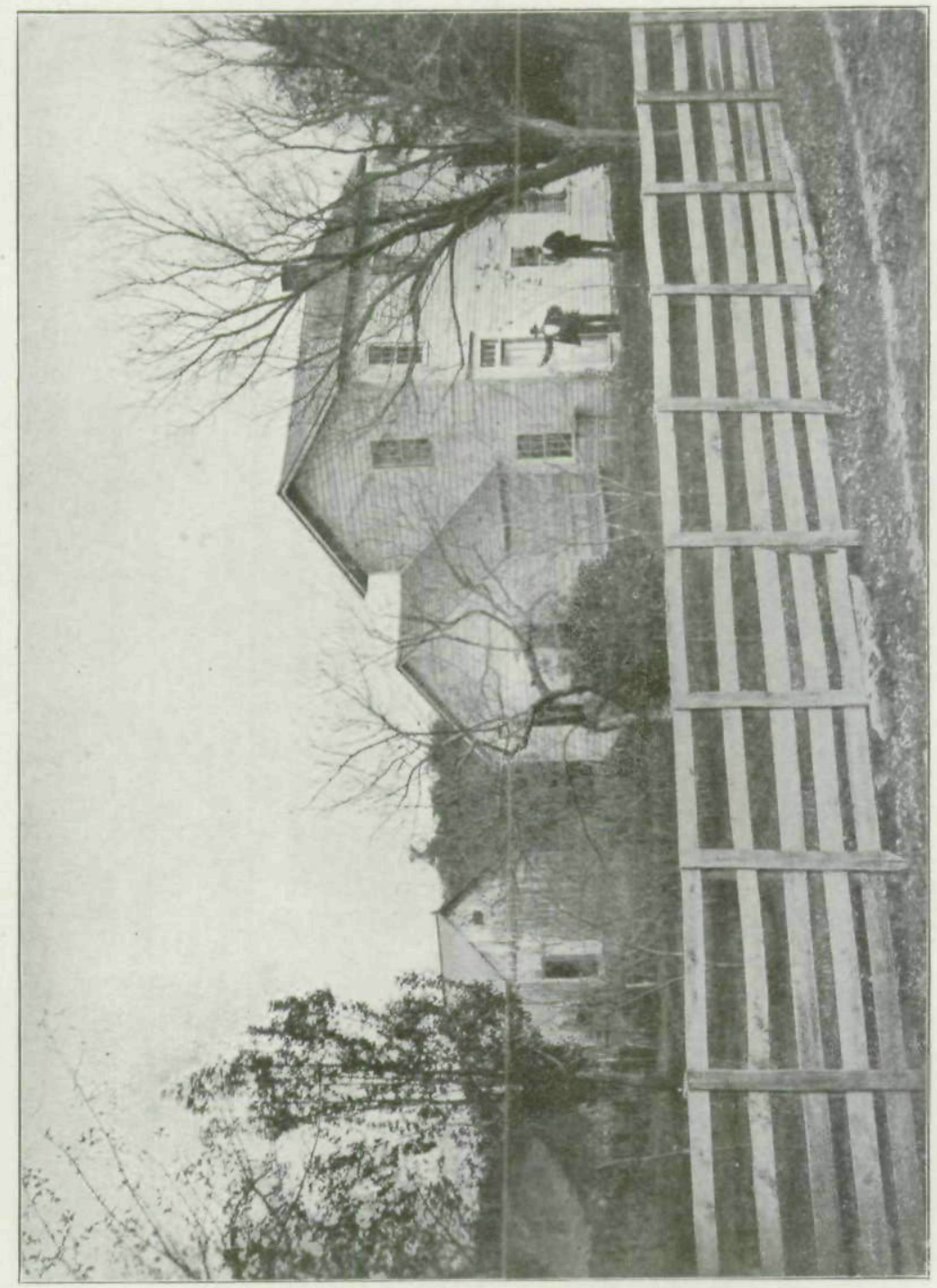

总 
ing sites staked, and some five or six started their cabins actually over and upon the big walnut and oak tree stumps they cut away. They looked out upon the river on the one side, through a fringe of tall trees, some of which still stand, and looked backward into a dense forest every tree of which is now gone, and their places taken by prize corn stalks, while the Des Moines Valley (C. R. I. \& P.) railroad skirts the hills in view of the old foundations.

One home, that of Abner Kneeland, was different from the rest, in that whereas the others were one story, one or two rooms, chink-an'-daubed, and elapboard roofed-all with such vulgar woods as black and white walnut, white oak and wild cherry, this one was framed of these woods, weather-boarded, without sheathing, finished and roofed with pine, for which lumber Mr. Kneeland made a special trip to St. Louis, taking boat from in front of his (to be) door, and landing the lumber from a boat on the same spot on his return. It was an immense structure $15 \times 21$ feet! A paneled pine door swung into a hallway about 6 feet wide, a stair rising about 8 feet from the door, and on the right of the hall. The hall led to the kitchen, which at that time was a lean-to of native boards nailed perpendicularly on stringers, and roofed with clapboards. Between the door and the foot of the stair, to the right, a double door led into the "big room," being the remainder of the first story without partitions. This double door was in fact two doors closing toward each other, and upon a partition piece built stationary, and finished to correspond with the casings, respectively, of the two doors. The paneling was of the vogue of the day. Entering you faced the mantel and the fireplace. It was not of the large and gaping sort of the neighboring houses, but in conformity with the cold-resisting walls, was built of dainty dimensions of 3 feet wide, three and a half high, and 2 feet deep. The mantel piece was a $2 \times 6$ pine board, rounded at the end corners, and resting on a $2 \times 3$ piece, which in turn rested on the edge of a slab about $2 \times 14 \times 40$ inches, whose corners were supported by two columns carved from, I suppose, about a $3 \times 4$ piece, so as to represent, in a small way, the ordinary ornamental work of that character. The walls were whitewashed mortar on split lath. These were nailed to the studding with their uneven surface far enough from the finished surface of the mortar, to admit of this surface running up flush with the edge of the frame timber at the top, so that when finished the white wall had a border four inches wide at the top, not of tinted paper or painted plaster, but of the axe-marked log on which the joints above rested. It was in this room that the great man had his library, ended his intellectual labors, performed his last marriage ceremonies, enjoyed the last of his happy domestic days and lay down to rest.

Taking the stairs, you landed in a counter-part of the hall below, except its length was lessened by a narrow, short bedroom above the lower landing. This left a narrow way of about 3 feet by which you walked around the open stairway, and neither this nor the stairs proper were protected by any sort of a balustrade. Turning at the back of the stairway, you entered, by a single door, the counter-part of the "big room" below, 
except that the ceiling was lower, and the windows, which in the room below were about three and a half feet from the floor, here were no more than a foot. Here was another flreplace like the one below, and in this room were placed the two or three beds of the many young folks. This was the mansion of Salubria, and as I believe, the grandest house when finished then in Van Buren county, if not in Iowa.

Mr. Aaron W. Harlan, of Croton, Iowa, came into the Des Moines valley in 1834. He is now 94 years of age, and writes as follows his recollections of Kneeland, depending solely on his memory of events that transpired 67 years ago:

I think it was in the fall of 1836 , the town of Farmington was new. Henry Bateman kept the only tavern in the place, and I was planning to start my mail-route. It was at Bateman's table I first heard the word "Salubria." It was never a laid out town as I understood; only meant for a little village as the home of people of congenial thought on religious matters. At that time banks were shaky and men in Boston that were supposed to have money to spare did not pay up, which fact may have changed plans considerably. The home of Jonas F. Denny had been purchased about two miles below Farmington on the Des Moines river. I think it was intended for each family to be the owner of its respective home. I saw Abner Kneeland many times. Sometimes he was working in his garden with a hoe. He always looked cleaner than the average citizen. I heard him give one lecture and only one, and that was accidental, at the house of old Isaac Gray, just below Athens. He was there by special invitation of most of the citizens of the vicinity. He did not take a text from the Bible or any other book, but his talk was truly interesting to me. He did not at any time manifest a disposition to make proselytes, but any man who wanted to hear something new on religious subjects could wake him up and was apt to wish that he bad not done so. He was a medium sized man, about 5 feet 9 and one half inches in height, and must have weighed nearly one hundred and seventy pounds. He was of light complexion and healthy appearance. He was considerably bald, what hair remained being perfectly white. I passed his house many times the first three years he lived in Salubria and called on him in a friendly way some three or four times. He called at my house once when a candidate for member of the territorial council. I went with him to Cassiday's where the speaking was to be. He had no magnetic or hypnotic influence, yet there was about him something that commanded respect.

Abner Kneeland called himself a pantheist, not accepting the name atheist, although repeatedly called so by others. A bibliography of his writings and a review of his editorial work show the mind of an able and versatile, if not. 
deep, scholar. He was a man naturally of much refinement and gentleness, and his followers were personally devoted to him. He is described as having a fine brow and eyes; as calm, courteous and gentlemanly in manner with a speech plain and direct. The impression among the people near his Iowa home, is that he was much misunderstood and that if he had not been persecuted before coming to Iowa, his peculiarities would not have reached so bitter and excessive a development.

A History of Van Buren county pays this tribute to the founder of Salubria: "Mr. Kneeland was a man of more than usual ability, a radical and individual thinker, and one whose strong opinions amounted to positive convictions. Mr. Kneeland's sincerity, which is conceded, has gone far toward softening the severity of judgment which at one time set in heavily against him, and what was sterling in his character is respected in his memory." An old and venerated minister in the State in writing of him says: "I remember that Abner Kneeland was a scarecrow name in New England, and when he came west sixty-five years ago, but it is long obsolete. I have sometimes thought that there was some excuse for him when 'Brimstone Corner' was made to set the standard of orthodoxy in Boston. We may be thankful that there have been changes in men's minds generally since then "with the progress of the suns." "

Although regarded with aversion by many during his life in Iowa Territory, 1839-'44, time has changed this feeling. Many now hold the various beliefs that he held without arousing opposition, comment or even curiosity.

THE TIDE of emigration is pouring in upon us an immense number of families this spring. Every steamboat from below is crowded with passengers. We have had twentyfive different arrivals by sixteen different steamboats.Dubuque Visitor, May 11, 1836. 
Copyright of Annals of Iowa is the property of State of Iowa, by \& through the State Historical Society of Iowa and its content may not be copied or emailed to multiple sites or posted to a listserv without the copyright holder's express written permission. However, users may print, download, or email articles for individual use. 